\title{
Tradução inclusiva e performativa: dossiê de um processo tradutório
}

\author{
Trupersa - Trupe de tradução \\ FALE-UFMG $^{1}$ \\ trupersa.ufmg@gmail.com
}

\begin{abstract}
In this paper, we intend to report the process of a translation proposal, developed from translation theoretical studies applied to dramatic texts from the V century B.C theater in Athens. Among many texts that are currently available, we chose the tragedy Persians, by the greek author Aeschylus. In the process, which happened in a seminar of Greek language and literature, where we did the instrumental translation in class and, a posteriori, individually, the students gave to the translation an established format with scenic and aesthetic concerns. Each student reports in this article his/her experience and his/her focus of interest; finally, we offer a translation tested by actors and directors and presented orally in class with a relative success.

KEYWORDS: translation theories; collective translation; poetic translation; Persians; dramatic text; Greek; Aeschylus.
\end{abstract}

O processo coletivo de tradução dos trezentos primeiros versos da peça Persas, do dramaturgo grego Ésquilo, realizado em um seminário de língua e literatura grega é nosso foco de reflexão. ${ }^{2}$ Procuramos harmonizar prática tradutória e leituras teóricas durante os quatro meses de trabalho no qual nos envolvemos em pesquisa e estudo a partir de dois princípios básicos: os efeitos de uma tradução "são imprevisíveis e potencialmente contraditórios" e "determinados por muitos fatores culturais e sociais diferentes". ${ }^{3}$ Assumimos, anuentes com Venuti, que a tradução alcançada pode destoar de alguns cânones eruditos; nesse caso, é bem provável que ela sofra repressão e até rejeição. Entretanto, se "cada tradução é tão única quanto o poema original”" e, além disso, se ela é "uma re-escritura, noutra língua, de uma leitura do texto", o abono a uma ou outra forma gerada se dá por uma conformidade de valores. Por isso acreditamos que

\footnotetext{
${ }^{1}$ A Trupe de tradução Trupersa está, nesta performance escrita, assim constituída: Alexandre Magalhães alexmagalhaesbh@gmail.com; Andréia Garavello - andreia.garavello@terra.com.br; Antônio Otávio Moura-aopmoura@dap.ufmg.br; Davi Robertson Baptista - a.englishclasses@gmail.com; Douglas Silva - douglas.two@gmail.com; Emerson Amaral - emersonamaral@gmail.com; Vanessa Ribeiro Brandão va17@hotmail.com; o presente artigo foi orientado e dirigido por Tereza Virgínia Ribeiro Barbosa virginiarb@yahoo.com.br.

2 Apresentamos aqui uma metodologia de tradução que vem, paulatinamente, se desenvolvendo na Faculdade de Letras da UFMG. O trabalho teve início em 2006 com duas atrizes, leitoras de grego antigo, e um diretor de teatro sob a coordenação da professora Tereza Virgínia Ribeiro Barbosa. A meta foi a tradução do prólogo de Eumênides, de Ésquilo. Os resultados da pesquisa foram divulgados na revista Cadernos de tradução, do Programa de Pós-Graduação em Estudos da Tradução da UFSC, disponíveis em http://www.periodicos.ufsc.br/index.php/traducao/article/view/1005/775.

${ }^{3}$ Cf. Venuti, L. Escândalos da tradução. Por uma ética da diferença. Tradução de Laureano Pelegrin. Bauru: EDUSC, 2002, p. 91.

${ }^{4}$ Cf. Laranjeira, M. Poética da tradução. Do sentido à significância. São Paulo: Edusp, 2003, p. 39.
} 
a experiência da tradução coletiva é válida no sentido de que representa várias leituras e, ao mesmo tempo, uma única. Não obstante as adversidades, demos início à nossa tarefa simplesmente pelo desejo de ver o texto grego encenado.

O primeiro impasse foi a escolha da edição a ser traduzida. Comparamos duas: a de Herbert Weir Smyth, Cambridge, 1926 - que pode ser encontrada em enciclopédias digitais, como Wikipédia e Perseus digital library -, e a de Gilbert Murray, de 1955, autorizada por Oxford e que pode ser encontrada no arquivo público Thesaurus linguae Graecae. Conferimos verso a verso as duas edições e percebemos que ambas são muito semelhantes. Assim, optamos pela edição de Smyth, por ser uma edição pertencente ao domínio público, o que nos isenta dos direitos autorais, e por guardar um nível de qualidade altamente satisfatório.

Também buscamos alguns dos melhores tradutores e teóricos antes de começar. Vimos que, de acordo com Max Bense, via Haroldo de Campos ${ }^{6}$ existem diversas informações num texto: a estética, a semântica e a documentária. Segundo esses autores, o texto traduzido poderia possuir uma dessas três informações ou, em casos mais bemsucedidos, mais de uma, em camadas diferentes. Na prática, portanto, traduzir seria uma atividade capaz de recuperar somente parte da informação e, para a tristeza geral, como tem sido regular acontecer, a principal perda nessa atividade ameaça ser aquela que se refere à estética do texto, que é, a um só tempo, delicada e arredia. Logo, não cabe ao tradutor "conseguir dizer" aquilo que o autor "quis dizer", mas escolher e, na escolha, realizar (indicar e sugerir) algo semelhante àquilo que o autor fez. ${ }^{7}$ Ou, revisitando Jorge Luís Borges:

Tivesse o poeta dito isso literalmente, teria sido bem menos eficaz. Porque, no meu entender, qualquer coisa sugerida é bem mais eficaz do que qualquer coisa apregoada... Mas quando algo é simplesmente dito ou - melhor ainda - insinuado, há uma espécie de hospitalidade em nossa imaginação. Estamos dispostos a aceitá-1o. ${ }^{8}$

\footnotetext{
${ }^{5}$ Cf. Laranjeira, op. cit., p. 30.

${ }^{6}$ Cf. de Campos, H. Da tradução como criação e como crítica. In: . (org.). Metalinguagem \& outras metas. Ensaios de teoria e crítica literária. São Paulo: Perspectiva, 1992, p. 32.

${ }^{7}$ Cf. Laranjeira, op. cit., p. 30.

${ }^{8}$ Cf. Borges, J.-L. A metáfora. In: Mihailescu, C.-A. (org.). Esse ofício do verso. Tradução de José Marcos Macedo. São Paulo: Companhia das Letras, 2000, p. 40.
} 
Transmitir, além das informações que se julgam mais importantes, a informação estética de um texto para um outro em uma língua muito diferente - como é o caso, do português para o grego - seria uma tarefa destinada apenas aos poetas? Há diferenças não só na língua (pela tonicidade, ritmo e métrica baseada em sílabas breves e longas), mas também em determinados padrões espaciais e temporais. O que nos resta, a nós que não estamos no patamar de Ésquilo? A contrapelo dos grandes estudiosos mencionados e correndo o risco prenunciado por Venuti, ousamos não acreditar completamente em tal preceito - a perda da informação estética - no projeto alentado. Postulamos que o texto traduzido proporciona elementos para a transmissão de informações estéticas outras, porque, apesar das diferenças e do trabalho de criação pessoal, o estético se transmite, ao menos em poesia, via meios pré-estabelecidos (ou por quebras de padrões) que acabam por funcionar de modos variados, mas correspondentes.

Ezra Pound, em seu $A B C$ of Reading, ${ }^{9}$ afirmou que, dentre as línguas que conhecia, a que mais lhe parecia possuir capacidade melopaica, a saber, meios para a utilização da sonoridade natural das palavras com um fim estético, era a grega. De Homero (Pound afirma: "eu nunca li meia página de Homero sem encontrar uma invenção melódica") ${ }^{10}$ a Calímaco (e seu famoso epigrama 28, o do kalós kalós que é respondido pelo eco num állos), passando obviamente por Safo (méte mói mélo, méte mélissa), toda a poesia helênica utiliza o som como ferramenta básica na construção poética, a começar pela riqueza métrica (ritmo também é som), caráter dessa poesia desde seus primórdios.

E Ésquilo, poeta em todos os sentidos, não poderia ser diferente. Suas tragédias têm como preocupação constante a sonoridade, que reflete, explícita ou sutilmente, informações que escapam da puramente semântica:

A poesia supera e suplanta o indizível por sua capacidade intrínseca de gerar sentidos não-referenciais, afastando-se da mimese em benefício da semiose, rompendo a linguagem tética através do processo de significância. Já que a poesia é responsável, muitas vezes, por dizer o não-dito. ${ }^{11}$

\footnotetext{
${ }^{9}$ Cf. Pound, E. ABC of Reading. London: Faber \& Faber, 1991, p. 43.

${ }^{10} \mathrm{Cf}$. Pound, op. cit., p. 43: I have never read half a page of Homer without finding melodic invention.

${ }^{11}$ Cf. Laranjeira, op. cit., p. 24.
} 
Neste sentido, a poeticidade do texto reside numa relação geradora de sentidos. Traduzir o poema é trabalhar a língua de chegada para se obter uma relação semelhante em nível de significantes que acarretará uma significância correlata à do poema original. De fato, em boa parte das traduções, essa informação estética sonora se perde em nome de uma tradição de leitura que sempre encarou o teatro como peça literária e que concretizou tal ideia em paráfrases tradutórias.

Some-se a isso que Ésquilo é um mestre do pitoresco. Seus personagens são criaturas coloridas, muitas delas sobrenaturais, orientais ou bárbaras e suas falas são abundantes em metáforas, provocando um agradável exercício do nosso imaginário. Tomemos, a título de exemplo, algumas metáforas que descrevem os persas e sua relação com o rei Xerxes. Elas, de forma imprecisa e quase borgiana, reportam (e enaltecem) à transformação da pólis grega, de antigos ideais e de deuses aristocráticos para os ideais e a força democráticos. Estão relacionadas, em geral, à vida animal e a uma crua brutalidade. O poeta toma um caminho banal, do senso comum, indicado por Aristóteles, em História dos animais (livro III, 488a) ${ }^{12}$ e define, tal como o filósofo, os persas - homens que são - como animais gregários, porque vivem organizados em grupos, da mesma maneira que a formiga, a abelha e o grou. Espera-se, todavia, para o homem, por excelência político, desempenho melhor. Ele, que possui o lógos, a capacidade da linguagem, de expressar o sentimento de dor e alegria, manifestar o certo e o errado, o justo e o injusto, deve se comportar de forma distinta. Assim, Ésquilo, ao afirmar que "um jugo lançado no pescoço do mar/ o audaz príncipe da Ásia de muitos homens/ desata sobre toda a terra/ um rebanho divino" (v. 72-75) e ao comparar os guerreiros persas a um "enxame de abelhas" (v. 128), evidencia um tratamento de massa por parte do rei aos seus súditos; retoma a submissão - condenável para homens gregos

\footnotetext{
${ }^{12}$ Cf. Aristóteles. História dos animais, I. Tradução de Maria de Fátima Sousa e Silva. Lisboa: INCM, 2006, p. 56: Atentemos agora nas diferenças de modo de vida e de actividade. Há animais que vivem em grupo e outros solitários, sejam eles do tipo que marcha, voa ou nada; outros ainda adoptam qualquer um destes dois modos de vida. Entre os que vivem em grupo como entre os solitários, uns têm instinto gregário, outros individualista. Das aves que vivem em grupo podemos referir a família dos pombos, o grou e o cisne (as rapinas nunca são gregárias); entre os que nadam, muitas espécies de peixes, por exemplo os chamados migradores, os atuns, as sereias e os bonitos. $O$ homem pertence aos dois tipos. $O$ instinto social é próprio dos seres que se mobilizam todos para uma actividade comum, o que nem sempre acontece com os gregários. Estão neste caso o homem, a abelha, a vespa, a formiga e o grou. De entre eles há os que obedecem a um chefe, como os grous e as abelhas; há também os que, como as formigas e milhares de outros seres, não têm chefe. Quer os animais gregários como os que levam uma vida solitária ou são sedentários ou se deslocam.
} 
- de meros animais em absoluta subserviência à tirania de um soberano ambicioso e arrogante; e enaltece o sistema democrático, a liberdade e identidade helênica, o solo e as próprias raízes do passado, bem como, no âmbito do sagrado, os próprios deuses ao invés da divinização de um rei-comandante. Nesse sentido, traduzir Os Persas de Ésquilo levando em consideração o que tantos desconsideram, como as funcionalidades sonora, metafórica e teatral, foi um desafio considerável, sobretudo porque o fazíamos de forma coletiva (e intencionalmente democrática, nos moldes helênicos).

Retomando, um teatro como o grego, conhecido há séculos e tradicionalmente traduzido como "literatura" dramática, carrega, já de antemão, o peso dessa característica que estabelece para ele um padrão de tradução, a nosso ver, diverso em sua intenção essencial dos dramaturgos áticos.

Comecemos pelo campo do enunciado oral, que deve funcionar publicamente para ser visto. ${ }^{13}$ Anular a fineza sonora é criminoso. Como simplesmente ignorar o grito poético da seguinte fala do coro?

Xopós

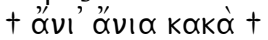

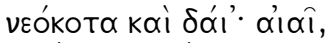

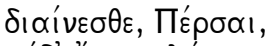

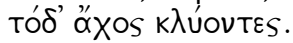
(v. 256-259)

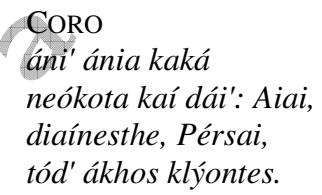

Seria impossível reproduzir tal passagem graças às barreiras linguísticas já afirmadas por Bense. A complexidade da tradução poética intimida o tradutor. No caso, o problema se relaciona ao significado além dos signos lingüísticos. Mas permanecer nesse ponto seria simplesmente desistir de traduzir qualquer texto que nos fosse apresentado e mais, desacreditar até mesmo daquelas traduções que consideramos de qualidade; a grande peleja foi tentar recuperar o máximo possível da informação buscando atingir o nível de geração interna dos sentidos. ${ }^{14}$

Na parte citada, o texto, em forma e conteúdo, é uma coisa só; por conseguinte, trata-se de uma fala completamente poética: um lamento. O poeta faz uma escolha sintático-sonora que simula um choro derramado, aberto em vogais claras e consoantes

\footnotetext{
${ }^{13}$ Trata-se mesmo de ver as palavras, de assistir ao som como um espetáculo que tem som, matéria, cor e brilho próprios.

${ }^{14}$ Cf. Laranjeira, op. cit., p. 12.
} 
oclusivas guturais e dentais que geram um efeito soluçante. É impossível não desejar manter essa beleza numa tentativa de reprodução dessa construção em vernáculo. Optamos pelo colorido oposto, o fechamento da vogal e o vibrato de "erres" misturados a oclusivas dentais e labiais:

Horror! Horror! Notícia de dor e terror! Ô! Ô!

Ao choro, povo persa, pelo anúncio avassalador.

A sonoridade não é a mesma, mas tentou-se recuperar não somente a propriedade fonética de cada palavra, mas inseri-la dentro de um contexto teatral. A nova possibilidade que a reprodução de um lamento daria à cena ganha o fluxo de um derramamento plangente pela consoante vibrante, velar, sonora " $r$ ", pela fricativa palatal surda "ch", pela vogal "o" tônica e oral privilegiada, que tem valor interjetivo para exprimir a emoção de um queixume. Se a cena malogra quanto à exibição espaventosa de um choro, tentaremos recuperá-la em outros trechos mais favoráveis; está registrado na concepção criadora da equipe que "os persas deverão ser espalhafatosos na elocução de seu lamento, sempre que possível" e, se a tradução trai o texto original, no que diz respeito a um comportamento não-verbal de lamento, ela recupera os aspectos mencionados, os quais julgamos análogos à estética da perda pranteada.

Tudo isso foi perseguido porque, insistimos, as peças a que nos referimos não eram escritas para leitura em público pelos atores, ou, silenciosamente, por solitários. Ésquilo, Sófocles e Eurípides programavam para seus textos um espetáculo com toda a semiótica teatral que fosse necessária, de modo que o texto corporificado pudesse ser visto, ouvido e experienciado em um espaço específico onde compareciam milhares de pessoas, artistas sofisticados, religiosos e gente comum. Este fato histórico, de suma importância, não deveria jamais ser ignorado no ato da tradução.

O que, infelizmente, acontece quando "lemos" traduções literárias de teatro grego? Sem dúvida, algumas traduções são belíssimas, no entanto elas próprias fornecem argumentos para diretores, encenadores e atores se permitirem, sem pejo, inúmeras "adaptações e mutilações" desses textos para a cena. Com razão argumenta-se: “o teatro grego não pode ser encenado ou entendido, o texto é pesado, pouco dramático e inadequado para um público intelectualmente despreparado". Esbarramos, antes de 
qualquer coisa, no propósito dessas traduções, feitas por acadêmicos, objetivando, quase exclusivamente, os leitores da própria academia. Esse tipo de tradução é a que predomina no Brasil. Para exemplificar, analisaremos, a seguir, dois tipos de tradução propostos por Venuti, apontando-os nas duas traduções brasileiras mais famosas de Persas e mostrando o que de útil pôde ser retomado daqueles e qual é nossa proposta. Focalizaremos dois tipos de tradução: aquela que se pauta pela precisão linguística e a que busca, acima de tudo, o efeito estético literário.

\section{A tradução filológica:}

Quando a tradução não é simplesmente ignorada, é provável que seja reduzida por completo à precisão linguística, especialmente pelos acadêmicos de língua estrangeira que reprimem o resíduo doméstico que qualquer tradução libera, e assim recusam-se a considerá-la como transmissora de valores literários na cultura-alvo. ${ }^{15}$

Ainda assim, esse tipo de tradução erudita - que não exclui também uma preocupação estética razoável - é vantajosa e útil por sua fidelidade ao texto original. Ela ensina, esclarece e interpreta o pensamento antigo. Ela guarda uma beleza grave e requintada; deixa a desejar, contudo, por não ser bem compreendida pelo público nãoacadêmico, o brasileiro comum.

\section{A tradução de efeito literário beletrística:}

Quando os textos do cânone acadêmico das literaturas estrangeiras são traduzidos por não-especialistas os acadêmicos das línguas cerram fileiras e assumem uma atitude de não-se-meta-no-meu-caminho. Eles corrigem erros e imprecisões em conformidade com padrões e interpretações eruditos, excluindo outras leituras possíveis do texto estrangeiro e outros públicos possíveis: por exemplo, as traduções beletrísticas que podem negligenciar a precisão em favor do efeito literário de forma a alcançar um público-leitor comum com valores diferentes. ${ }^{16}$

Sem dúvida, a vantagem dessa tradução é a possibilidade de alcançar um público não-acadêmico, mas, algumas vezes, suprime versos quase inteiros e, outras vezes,

\footnotetext{
${ }^{15}$ Cf. Venuti, op. cit., p. 67.
}

${ }^{16}$ Cf. Venuti, op. cit., p. 68-69. 
acrescenta diversas palavras não existentes no texto original, ocasionando, geralmente, uma tradução bem mais extensa que o texto original. Outro problema deste tipo de tradução é que tendem a ser literárias, não-teatrais e, muitas vezes, como afirmamos, esses textos são utilizados por diretores que inserem e retiram versos visando à encenação de um texto que "julgam” ser literário. Parece, todavia, que há algo perverso e um pouco cômico neste processo, uma vez que o teatro grego é transformado em literatura e esta é, por sua vez, transformada em teatro. Não é difícil perceber que é grande a distância entre a peça escrita em grego para ser encenada e a peça adaptada a partir de uma tradução de cunho literário. Podemos dizer que o teatro grego encenado hoje é praticamente tradução de uma tradução, ou simulacro de um simulacro.

Considerando-se o que até aqui foi dito, buscamos conciliar os tipos de tradução mencionados com o fator teatral de Persas em nossa tradução. Assim, levamos em conta três fatores: o público-alvo (expectadores de todos os gêneros e nível de escolaridade), a precisão linguística, o efeito teatral (já que não estamos trabalhando com um texto puramente literário, mas também performático).

O principal deles é exatamente o menos observado nos que privilegiam a precisão linguística: pessoas não-eruditas devem ser capazes de entender a história sem que precisem recorrer ao dicionário, pois estarão em um espetáculo teatral. Com isso em mente, preferimos termos mais familiares em português, conforme mostrado abaixo:

\begin{tabular}{|c|c|c|}
\hline$\phi$ & Trupersa & Jaa Torrano: \\
\hline 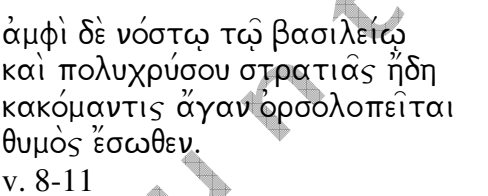 & $\begin{array}{l}\text { Mas, quanto ao regresso do rei } \\
\text { e ao mui dourado exército, inda agora } \\
\text { o peito, profeta de desgraças, } \\
\text { tanto me agita no íntimo. }\end{array}$ & $\begin{array}{l}\text { Ao pensar no regresso do rei } \\
\text { e do multiáureo exército, já } \\
\text { um maligno pressago ímpeto } \\
\text { sobressalta íntimo }\end{array}$ \\
\hline 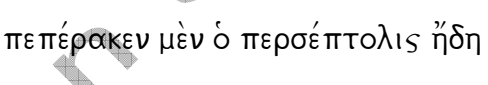 & $\begin{array}{l}\text { Atravessou... assolador de cidades, } \\
\text { o real exército, pela }\end{array}$ & O turrífrago exército do rei \\
\hline 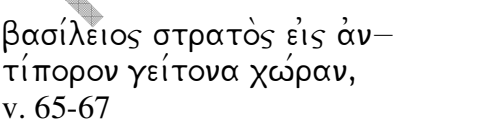 & porta oposta na terra vizinha & $\begin{array}{l}\text { já transpôs a fronteira terra } \\
\text { vizinha }\end{array}$ \\
\hline
\end{tabular}

A tradução de Torrano é louvável e exata por fazer a correspondência de um por um (a cada termo grego um termo em português), como, por exemplo: по入uxpúбou por

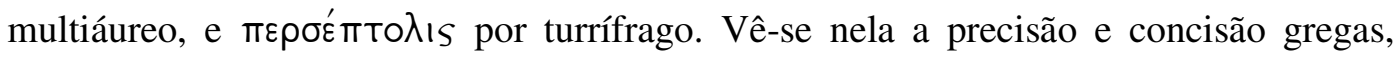


porém ele utiliza termos eruditos e pouco acessíveis a um público espectador mediano. A correção, a adequação lexical, a manutenção da ordem das palavras, considerando-se o entendimento do que não tinha correspondentes no português, foram bastante bemsucedidos, entretanto sua leitura, à primeira vista, para público desavisado, não é eficaz.

Passemos a um outro trecho:

\begin{tabular}{|c|c|c|}
\hline & Trupersa & Mário da Gama Kury \\
\hline & desata sobre toda a terra & levou por duas rotas diferentes \\
\hline ว́ & um rebanho divino & o seu rebanho humano incalculável, \\
\hline 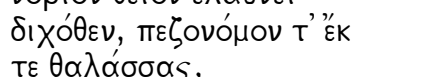 & $\begin{array}{l}\text { em dupla via, por terra } \\
\text { e por mar. }\end{array}$ & $\begin{array}{l}\text { disposto a conquistar o mundo } \\
\text { inteiro. }\end{array}$ \\
\hline 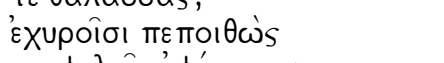 & Fortes prevalecem & Para guiar o exército e a frota. $\mathrm{O}$ \\
\hline 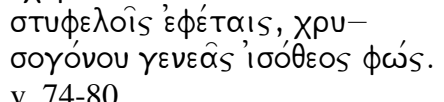 & $\begin{array}{l}\text { com severos juízes, } \\
\text { raça da chuva dourada, divina luz. }\end{array}$ & $\begin{array}{l}\text { descendente da chuva de ouro, } \\
\text { mortal igual ao deuses }\end{array}$ \\
\hline
\end{tabular}

À primeira vista nem parece ser o mesmo texto, porque Gama Kury, apesar de utilizar termos de fácil compreensão ao público em geral, ácrescenta versos e sentenças inteiras para explicar o sentido do que existe condensado no texto grego.

Buscamos, assim, na medida de nossas capacidades, conciliar precisão linguística, recuperação estética e efeito teatral (o terceiro fator a ser exemplificado) sem desconsiderar o público-alvo. Fomos constrangidos a inversões para melhorar a sonoridade e ordem das palavras e alcançar uma sintaxe mais imediata para a compreensão do texto em português, atendendo aos supostos espectadores brasileiros multinivelados.

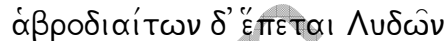

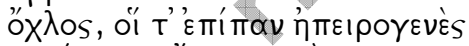

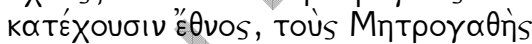

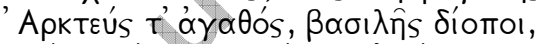

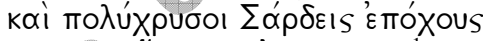

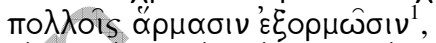

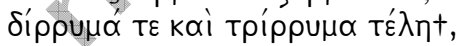

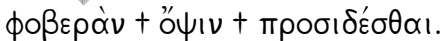

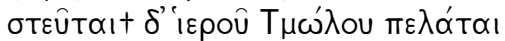
$\zeta u \gamma o v^{2} \stackrel{\alpha}{\alpha} \mu \phi ı \beta \alpha \lambda \varepsilon v^{3} \delta o u ́ \lambda ı v^{\prime} \mathrm{E} \lambda \lambda \alpha^{\prime} \delta$, v. 41-50

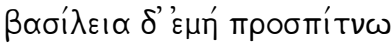

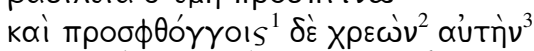

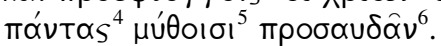
v. $152-154$
De vida mansa se ajunta a legião 41

lídia, eles que sobretudo as etnias continentais governam, Metrogates e belo Arcteu, reis vigias e a polidourada Sardes enviam ${ }^{1}$ os montados nos muitos carros de duplo e triplo-eixo completos medonha cena a ser vista.

Ameaçam os vizinhos do santo Tmolo lançar $^{3}$ jugo $^{2}$ escravo à Grécia,

Rainha minha, eu me curvo E com palavras ${ }^{5}$ acolhedoras ${ }^{1}$ todos ${ }^{4}$ devem ${ }^{2}$ saudá $a^{6}-l a^{3}$. 
Os números sobrescritos nas palavras indicam as correlações entre as traduções. Entendemos que, para o nosso propósito, não bastava a precisão nem as facilitações de compreensão pela paráfrase; queríamos que o texto funcionasse como teatro em linguagem de comunicação imediata. Chegamos ao resultado abaixo, o qual submetemos a uma encenação. Eis os versos de 1-299, baseados em texto grego da edição de Smyth (Cambridge, 1926).

TEP $\Sigma A I$

Xopós

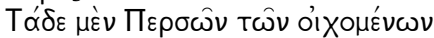

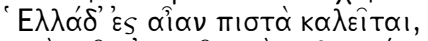

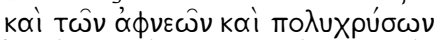

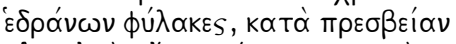

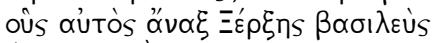

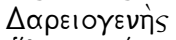

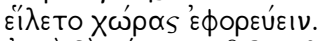

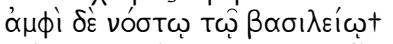

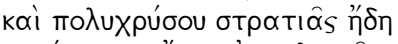

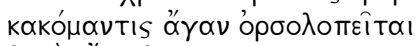

$\theta u \mu o ̀ s " ~ ह ै \sigma \omega \theta \varepsilon v$.

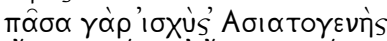

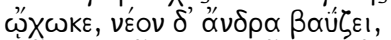

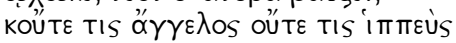

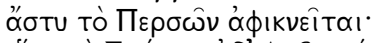

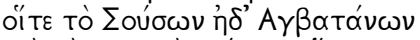

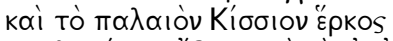

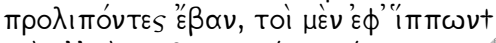

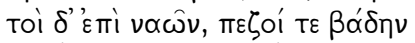

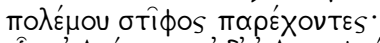

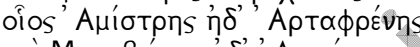

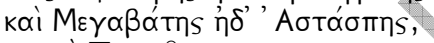

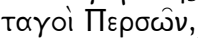

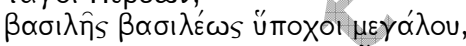

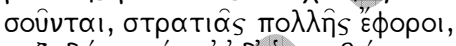

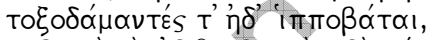

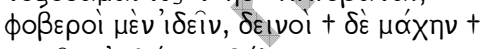

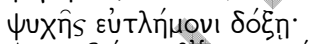

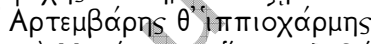

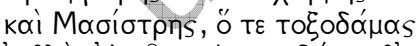

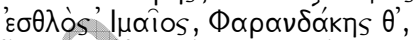

"i

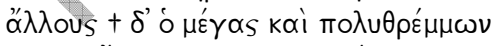

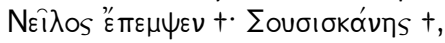

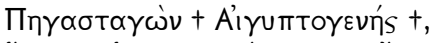

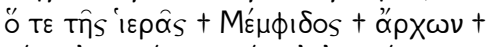

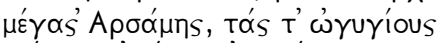

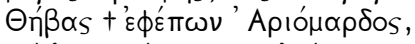

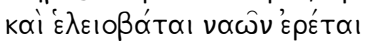

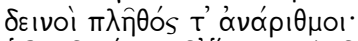

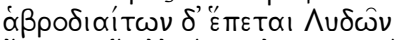

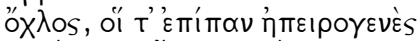

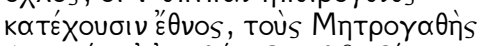

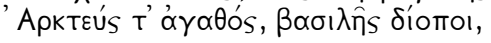

\section{PERSAS}

Coro:

Isto aqui - dos persas que se foram

contra a terra grega - chamam fiéis,

das ricas e mui douradas

sedes somos guardas... por velhice...

05

que o próprio rei Xerxes soberano

05

filho de Dario

escolheu para velar a terra.

Mas, quanto ao regresso do rei

e ao mui dourado exército, inda agora

o peito profeta de desgraças

10

tanto me agita no íntimo.

Pois partiu toda a força gerada na Ásia

e ele gane por um novo homem...

nem um mensageiro, nem um cavaleiro

à capital dos persas chega;

e eles de Susa e de Ecbátana

mais a antiga muralha císsia

deixando, partiram uns sobre cavalos

outros sobre navios, e marchando sobre os pés

formam uma tropa de combate.

Dentre eles Amístres, Artafrenes

e Megabates e ainda Astaspes,

comandantes dos Persas,

reis submissos ao grande Rei,

25 comandantes de numerosas hostes,

uns arqui-arqueiros, outros cavaleiros,

temíveis de ver, terríveis nas batalhas,

de alma com inquebrantável opinião;

Artembares luta do carro

30 e Masistres arqueiro e o

nobre Imeu e Farandaques,

e o comandante de cavalos Sostanes

e outros o grande e fecundo

Nilo enviou: Susiscanes,

Pegastagon, filho do Egito

e o príncipe da sagrada Mênfis

grande Arsames; o governante

da ancestral Tebas Ariomardos

e nos brejos... remadores de barcos...

terríveis turbas incontáveis.

De vida mansa se ajunta a legião

lídia, eles que sobretudo as etnias

continentais governam, Metrogates

e belo Arcteu, reis vigias

e a polidourada Sardes enviam os montados 


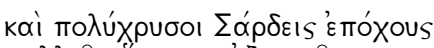

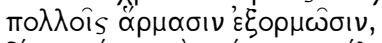

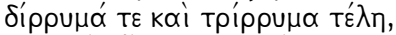

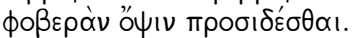

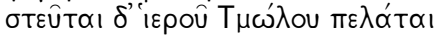

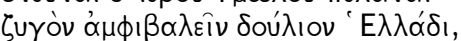

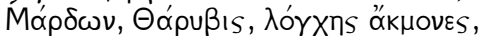

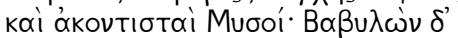

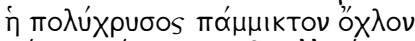

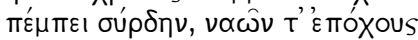

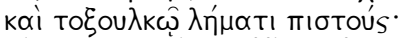

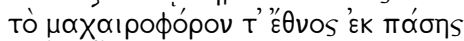
Aoías है $\pi \varepsilon T \alpha$ ।

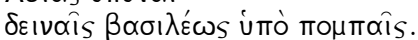

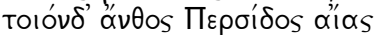
o’X

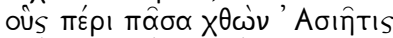

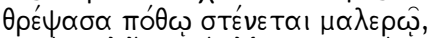

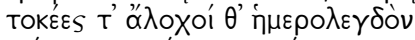

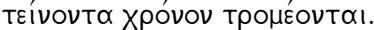

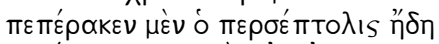

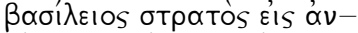

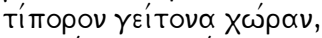

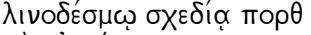

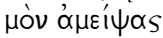

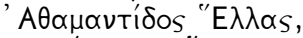

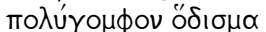

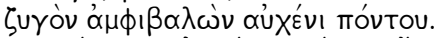

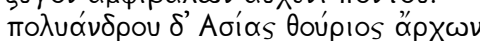

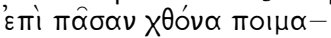
vópı

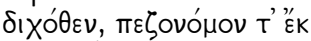

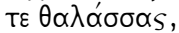

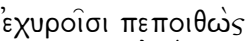

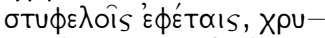

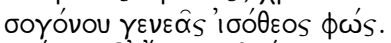

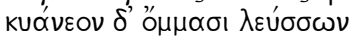

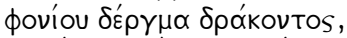

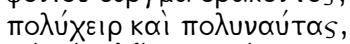

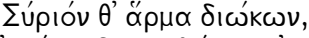

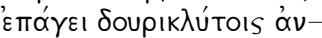

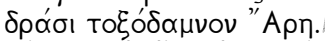

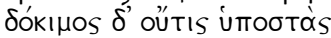

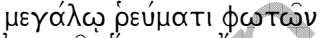

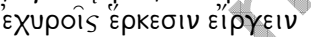

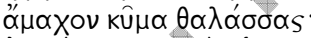

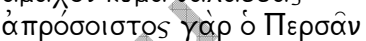

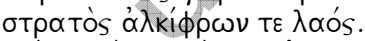

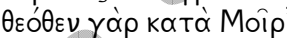

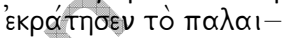

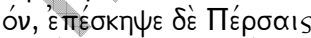

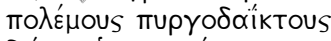

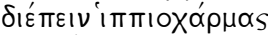

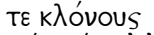

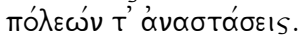

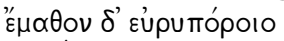

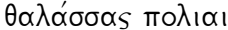

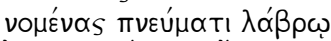

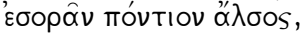

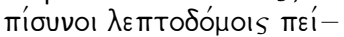
$\sigma \mu \alpha \sigma 1 \lambda \alpha-$

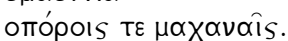

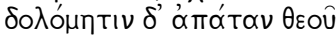

nos muitos carros

de duplo e triplo-eixo completos!

Medonha cena a ser vista!

Ameaçam, os vizinhos do santo Tmolo

lançar jugo escravo sobre Grécia,

Mardo e Taribis, de lança incansável,

e os mísios lança-dardos; e a Babilônia

polidourada envia uma turba

misturada em fila, e os montados nas naves e os que confiam na tensa intenção do arco.

Com cimitarra, povos de toda

Ásia vêm

sob a terrível companhia do rei.

Tal flor da terra persa

parte... dentre os homens

pelos quais todo chão Asiático

que os nutriu com desejo veemente geme,

pais e esposas a contar os dias,

esticando o tempo tremem.

Atravessou... assolador de cidades,

o real exército, pela

porta oposta na terra vizinha,

da trama de barcos

uma via cruzando

o estreito grego Atamantida.

Caminho muito articulado

Um jugo lançado no pescoço do mar.

o audaz príncipe da Asia de muitos homens desata sobre toda a terra

um rebanho divino

em dupla via, por terra e por mar.

Fortes, prevalecem com severos juízes,

raça da chuva dourada, divina luz.

E um profundo azul fitando com olhos, uma sangrenta visão de dragão, muita mão, muito remo, um carro Sírio acelerado conduz um Ares flecheiro contra homens lanceiros.

De fato, ninguém se impõe ao grande fluxo de luz...

é como deter com duros muros a incansável onda do mar.. pois imbatível é o exército persa e o povo de peito ardoroso. De um deus, a Moira decretou, há muito.. e impôs aos Persas combates arrasadores arranjar, e, ao piloto, tumultos na cidade insurgir. Aprenderam do oceano de amplo caminho luzido no sopro furioso a olhar um bosque no mar fiados em finos nós

que servem como passagens mecânicas. Mas da dolosa fraude de um deus 


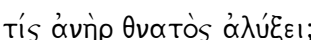

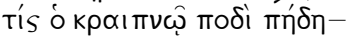

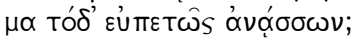

фı

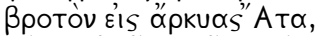

Tó $\theta \varepsilon v$ OÜ "

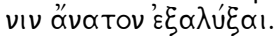

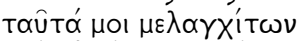

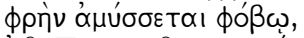

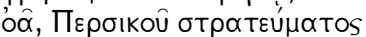

ТоUิ $\delta \varepsilon, \mu \eta \dot{~ \pi o ́ \lambda i s ~ \pi u ́ \theta \eta-~}$

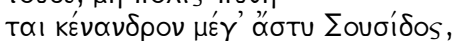

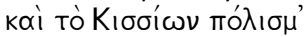

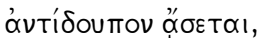

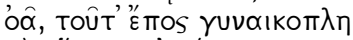

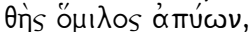

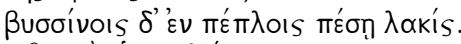

$\pi \hat{\alpha} S \gamma \alpha \grave{\rho} i \pi m \eta \lambda \alpha^{\prime} \alpha_{S}$

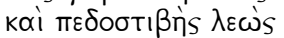

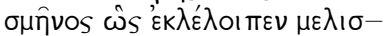

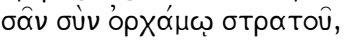

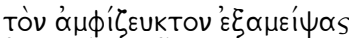

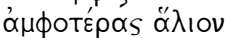

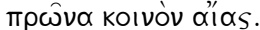

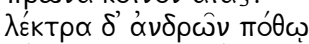

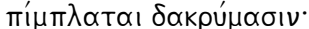

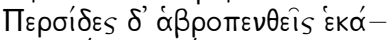

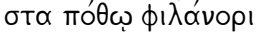

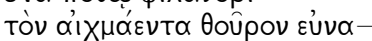

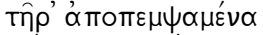

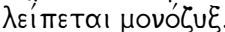

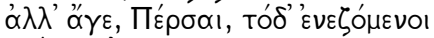

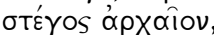

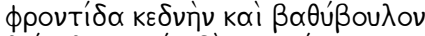

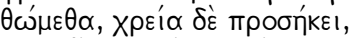

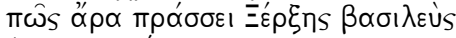

$\triangle \alpha \rho \varepsilon ı \gamma \varepsilon v \eta \dot{s}$,

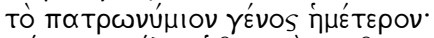

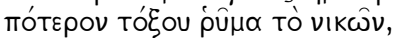

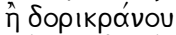

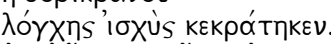

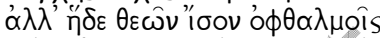

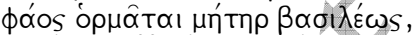

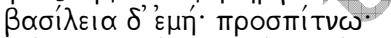

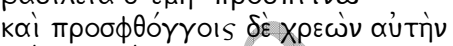

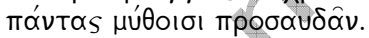

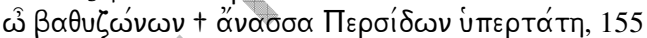

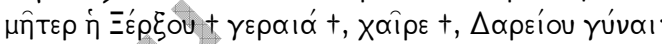

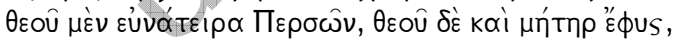

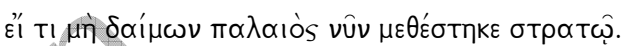

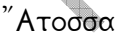

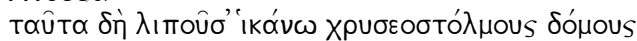

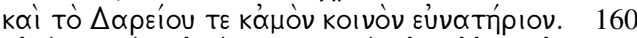

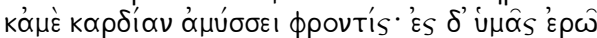

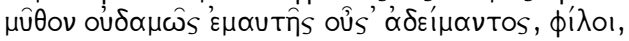

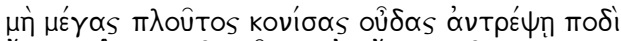

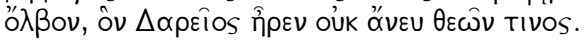

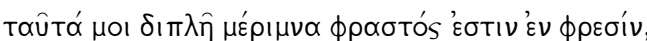

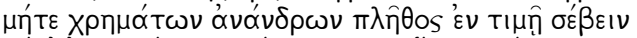

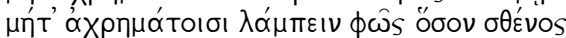

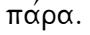

qual homem perecível escapa?

Qual o que firme no pé,

com passada ágil, esquiva?

Pois a ilusão amiga, sedutora atrai

o mortal para redes

de onde não é dado

a ele ileso escapar.

15 Por estas coisas em mim negro manto no

âmago é dilacerado pelo medo

ôa campanha da Pérsia!

Desta, a cidade não tenha notícia

- vazia de machos - a mega torre de Susa

e que pela capital da Císsia

ecoe os cantos

ôa! Esta palavra, um bando de fêmeas

clamando, reunidas...

e que no linho das vestes recaia um rasgo.

Pois todo cavaleiro

e povo marchador

como um enxame de abelhas

foi-se junto ao capitão do exército

ligando e atravessando

ambas as pontas

pelo mar... para uma terra comum...

E com desejo os leitos dos machos

se enchem de lágrimas!

35 Nas persas um pranto macio

cada uma com desejo afetuoso do

lanceiro feroz.

A que despediu o marido,

é deixada sozinha.

Mas vá, persas!

sentemos neste teto ancestral

para que um pensar confiante e profundo

mostremos, pois a demanda se aproxima

Como então age o rei Xerxes

filho de Dario

patrono de nossa raça?

Qual vence? O arco tenso

ou a cabeça do bronze?

A força da lança terá triunfado?

Mas eis que uma luz igual à dos deuses

aos olhos avança, a mãe do rei,

rainha minha. Eu me curvo.

E, com palavras acolhedoras,

todos devem saudá-la.

Oh prima dona das persas de cintura fina

- A velha mãe de Xerxes! - Salve, mulher de Dario!

De um deus dos persas amante e naturalmente mãe de um

deus

Se uma divindade antiga agora não abandona o exército.

Atossa:

Justo por essas coisas avanço, deixo moradas mui douradas

e meu quarto comum com Dario.

$\mathrm{E}$ uma angústia me dilacera o coração. $\mathrm{E}$ a vós direi

uma palavra: de modo algum eu mesma estou sem medo, amigos

não revire a grande riqueza em terra pulverizando com os pés uma felicidade que Dario ergueu não sem algum

deus!

Por isso dupla e indizível inquietação há em meu peito, 165 nem dignamente riquezas sem guardas a multidão respeita, 


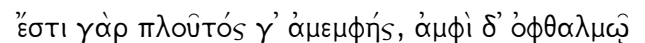
фóßos:

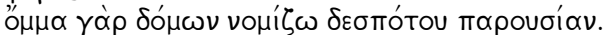

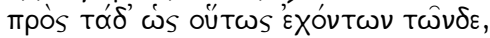
бú $\mu$ ßou

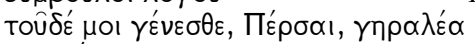

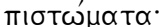

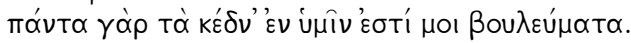

Xopós

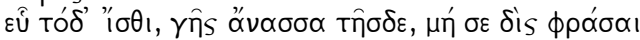

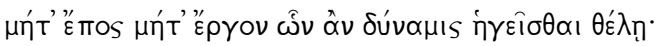

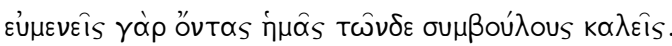

"Атоб $\alpha$

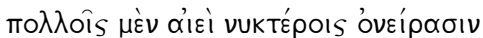

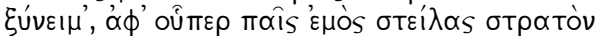

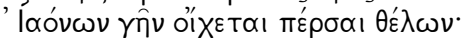

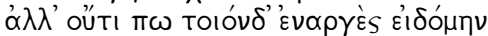

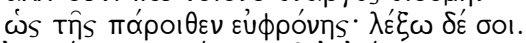

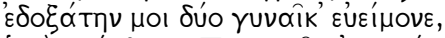

$\grave{\eta} \mu \varepsilon \dot{\varepsilon} \nu \pi \varepsilon \pi \lambda$ о

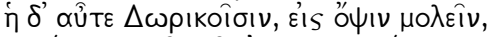

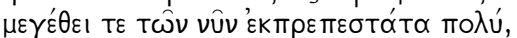

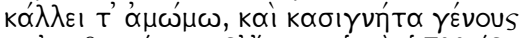

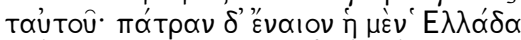

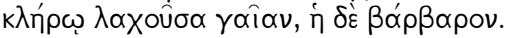

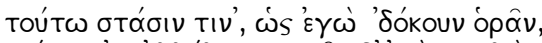

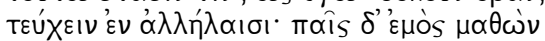

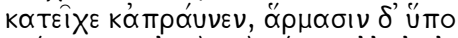

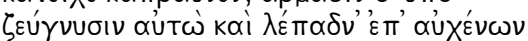

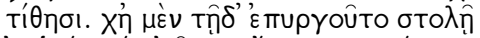

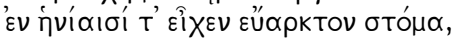

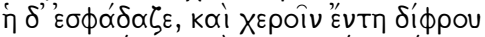

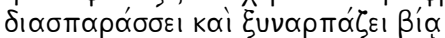

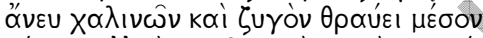

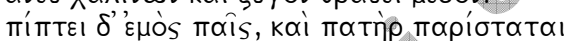

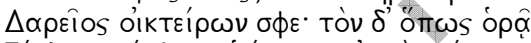

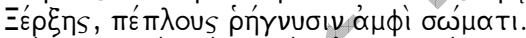

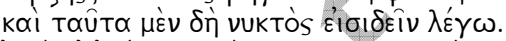

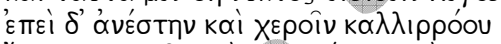

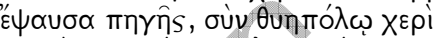

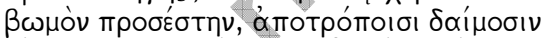

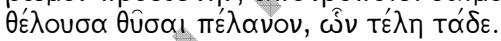

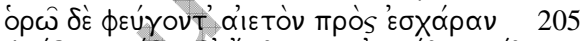

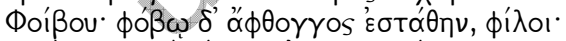

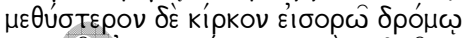

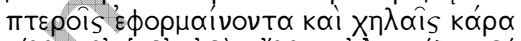

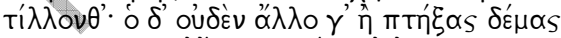

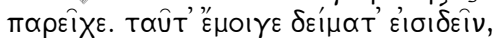

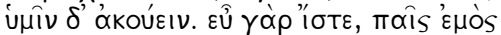

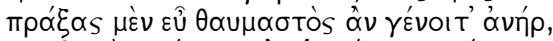

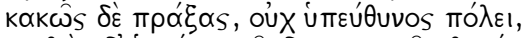

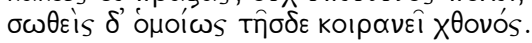

Xopós

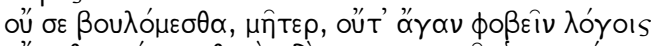

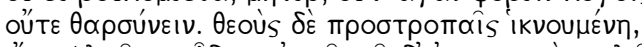
ह้ nem homens sem riquezas brilham conforme seu vigor.

Pois existe uma riqueza intacta, e, em

torno dos olhos, medo...

- é que considero olho da casa a presença senhor.

Diante disso, nessa situação,

conselheiros de palavra, 170

isso sede para mim, persas, velha garantia

pois todo o bom conselho, para mim, em vós está.

CORO

Isto bem sabes, soberana desta terra, tu não pedes duas vezes nem palavra, nem ação, de que, sendo capaz, deseje tomar frente para isso, nos chamas, a nós, os gentis conselheiros.175

AtossA

Certamente, sempre, com muitos sonhos noturnos, convivo, desde quando meu filho preparado, com o exército, parte para a terra dos Jônios desejando saquear;

mas... um assim... tão claro... ainda não vi como ontem, no doce momento. Direi a ti: pareceram, a mim, duas mulheres bem vestidas a avançar... para a vista... uma vestida à moda persa, a outra, ao contrário, dórica, no aspecto veio. $\mathrm{Na}$ grandeza, comparadas às de agora, muito maiores e também na beleza sem mancha, e ambas irmãs da mesma raça: mas, como pátria, habitava uma delas 186 a terra grega obtida com sorte pelos deuses, a outra, a bárbara.

Ambas frente a frente, como julgo ter visto,

a provocar uma a outra... mas... meu filho, percebendo, prevalecia e acalmava, e no carro subjugou-as e pôs correias nos pescoços. Uma se exaltava com o adereço, nas rédeas tinha mansa a boca,

mas a outra se agitava, e com as mãos os arreios do carro despedaça e o arrebata pela força,

sem os freios, também o jugo parte ao meio.

Meu filho cai, e o pai se coloca ao lado,

Dario sofre por ele... e assim que Xerxes

o vê, as próprias vestes rasga ao redor do corpo.

Essas coisas de fato digo ver de noite...

Mas em seguida me levantei e as mãos lavei no belo fluxo da fonte, com mão sacrifícial, do altar me aproximei, querendo oferecer

libação - para deuses apotropeus - da que é pr'esse o fim.

$\mathrm{E}$ vejo... fugindo... uma águia... para o altar de Apolo; apodera-se de mim o medo e emudeço, amigos! De repente, enxergo um falcão em corrida que se lança com as asas e com o bico arranca a cabeça; a águia... nada mais, senão, um corpo acuado... entrega. Horrível para eu própria ver isso,

e para vós... ouvir. Pois bem sabes... meu filho bem-sucedido sendo, admirável homem seja! mas males sucedendo... não presta contas à cidade, está salvo e da mesma forma governará a terra.

CORO

Não queremos, mãe, nem muito te amedrontar

com palavras, nem encorajar. Aos deuses indo com súplicas, se algo sinistro viste, deles exige que se cumpra o 


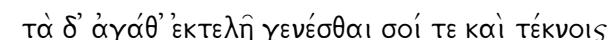

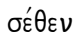

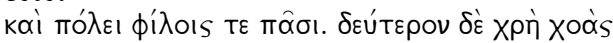

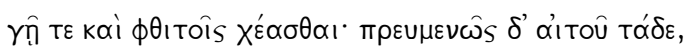

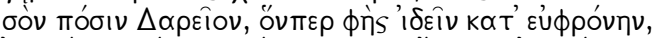

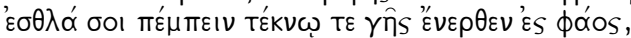

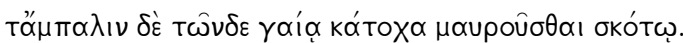

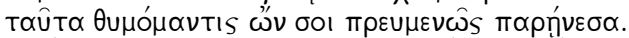

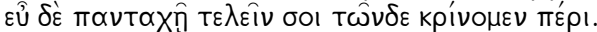

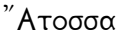

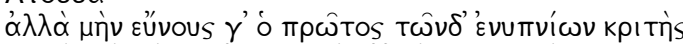

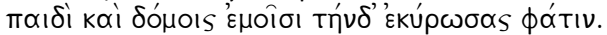

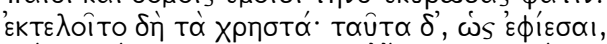

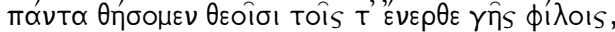

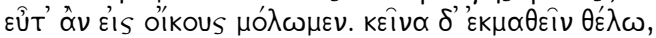

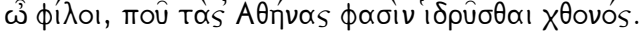

Xopós

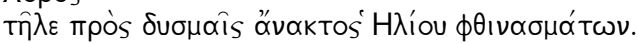

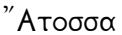

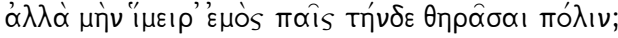

Xopós

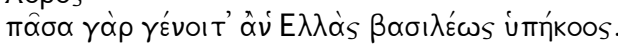

"Aтобб $\alpha$

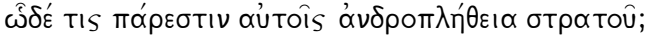

Xopós

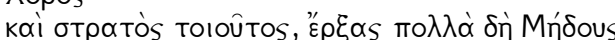

køká.

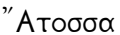

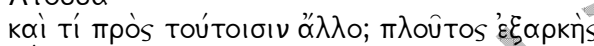

бómols;

Xopós

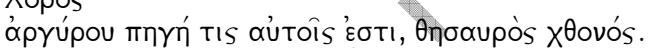

"Атобб $\alpha$

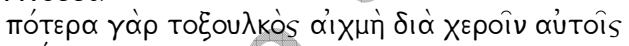
$\pi \rho \varepsilon ́ \pi \varepsilon ı$;

Xopós

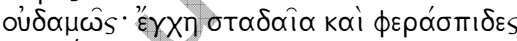
бoraí.

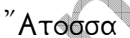

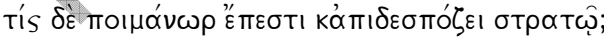

Xopós

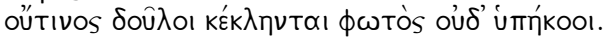

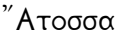

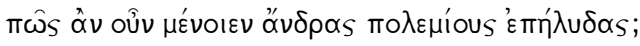

Xopós

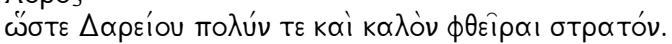

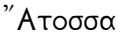

e que favores perfeitos a ti, a teus filhos,

à cidade e a todos os amigos sejam. Em seguida convém

libações

verter à Terra e aos mortos. Graciosamente exige isto 220

do teu marido Dario, que dizes ter visto em doce momento: coisas propícias a ti e a teu filho enviar do subterrâneo para a luz

e, o contrário, em terra, reter lá embaixo, nas trevas.

Sendo o peito um profeta, isto a ti, benevolente, recomendo. Que venha, em toda parte, um bem acabar, estas coisas a ti predico! 225

Atossa

Sim! Claro! Juiz bem disposto deste visões - o primeiro! com meu filho e com minhas moradas, deste a sentença! Que se cumpram os deveres. E as coisas como desejas! Tudo daremos aos deuses e aos queridos enterrados assim que retornarmos para casa. Mas isto quero saber, 230 ó amigos, onde da terra dizem Atenas estar situada?

CORO

Longe, ao ocidente, pelos declínios do soberano Sol...

Atossa

Mas... então... meu filho desejava capturar a cidade?

CORO

Pois toda a Grécia poderia vir a ser sujeita ao rei.

ATossA

Ah... então há com eles um exército de muitos...

CORO

E tal exército muitos males fez aos Medos...

Atossa

E o que mais há para estes? Riqueza bastante... nas casas?

CORO

Veios de prata há para eles, tesouros da terra...

Atossa

Que, pois, lhes convém? Flecha atirada resplandece nas mãos?

CORO

Não mesmo. Lança ereta e escudos equipados.

AtossA

Mas... quem é o pastor-comandante e governa no exército?

CORO

De ilustre nenhum são chamados servos, nem subalternos.

Atossa

Como então resistiram aos valentes combatentes estrangeiros?

Coro

Disso é que eliminaram o numeroso exército de Dario.

Atossa 


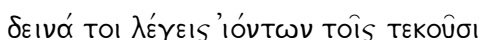

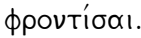

Xopós

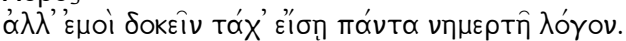

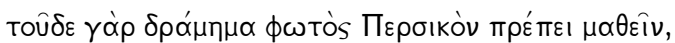

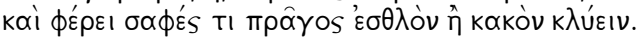

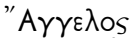

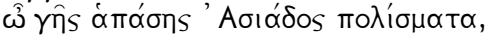

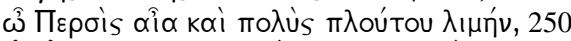

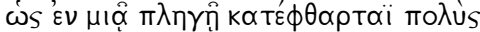

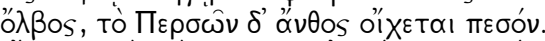

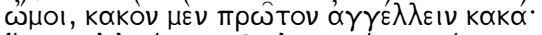

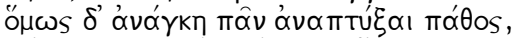

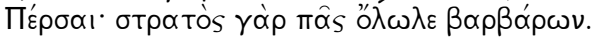

Xopós

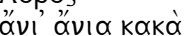

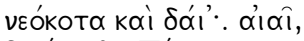

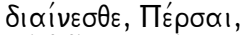

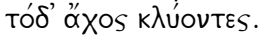

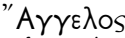

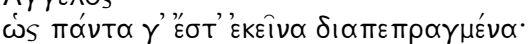

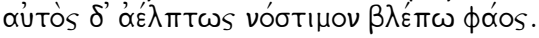

Xopós

กิ $\mu$ okpoßíotos

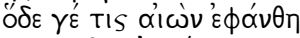

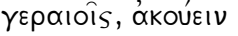

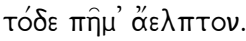

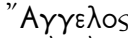

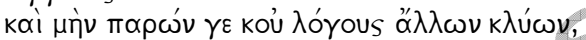

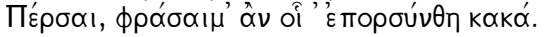

Xopós

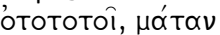

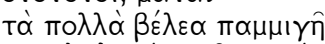

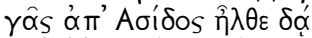

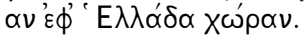

270

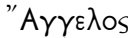

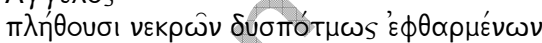

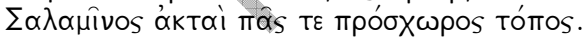

Xopós

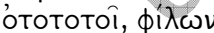

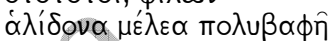

275

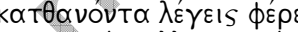

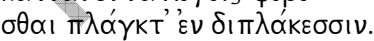

"A

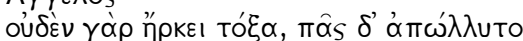

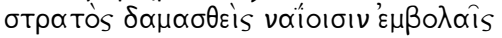

Xopós

"I

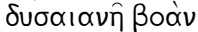

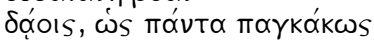

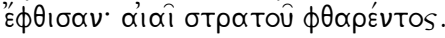

Dizes coisas terríveis de pensar para os pais dos que partiram

CORO

Mas me parece que logo saberás de tudo por uma honesta palavra,

pois a corrida desta luz pérsica mostra-se clara de entender, e traz algum fato evidente, mau ou bom de se ouvir..

Mensageiro

Oh, vilas de toda terra asiática

oh, chão persa, limiar de muita riqueza,

como, num só golpe, foi despedaçada a muita

felicidade! Tombou, foi-se a flor dos persas!

Ai de mim! Desgraça! Primeiro anunciar desgraças...

E carece, igualmente, desembrulhar todo sofrimento!

Persas! Então, todo o exército dos bárbaros está acabado.

CORO

Horror! Horror! Notícia de dor

e terror! Ô! Ô!

Ao choro, povo persa,

pelo anúncio avassalador

MENSAGEIRO

Assim mesmo que tudo aquilo se passou.

Eu mesmo, por acaso, vejo a luz do retorno.

CORO

De fato, uma vida comprida

Esta se revela

a velhos, ao escutarem

estes pesares inesperados.

Mensageiro

Pois testemunha, não ouvinte de alheios, persas, posso anunciar males praticados

CORO

ôôô̂! Em vão

as muitas armas misturadas

da terra da Ásia partiram...

pr'o chão hostil da Grécia.

MENSAgeiro

enchem, miseravelmente, de cadáveres arruinados, toda a costa de Salamina e lugares próximos.

CORO

ôôôo, de amigos

corpos abatidos, afundando, a rolar pelo mar, $\quad 275$

mortos... falas... a boiar

em suas longas saias errantes

MENSAGEIRo

Não resistiu o arco, inteiro sucumbiu

o exército, domado com chicotadas dos navios

CORO

Grita "infortunado"! Aos persas

um lamentoso brado!

Aos infelizes, tudo perversamente

os deuses apresentam. Ai! ai do exército destruído! 


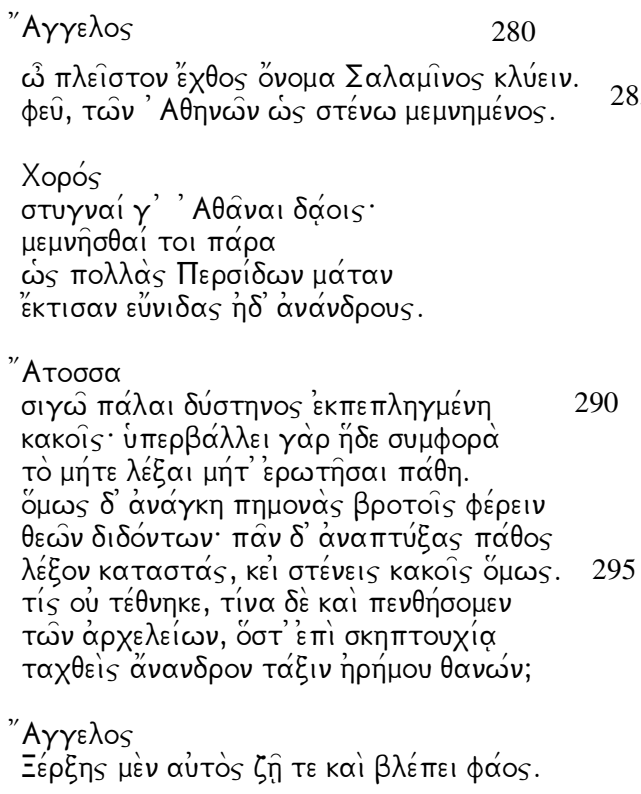

MENSAGEIRO

Oh, nome mais odioso de escutar, Salamina! ô, como gemo quando de Atenas me lembro!

Coro

Odiosa, para os miseráveis, sim, é Atenas!

Lembrar, sim, é possível...

de como muitas das persas, por nada, deixou viúvas e sem filhos...

Atossa

Guardo há muito o silêncio, miserável abatida por males. Tal desastre supera

o falar e o perguntar sobre os sofrimentos. Pois então que os mortais suportem as aflições pelos deuses dadas; abrindo todo o sofrimento, diga-o gota-a-gota, se assim gemes pelos males. 295 Diga qual dos chefes não está morto, por qual choraremos, quem, na posse do cetro, abandona pela morte seu posto, sua tropa sem senhor

MEnSAgeiro

Xerxes, ele vive e vê a luz

Assim a Trupersa buscou, ao traduzir os primeiros trezentos versos de Persas, manter-se na fronteira de métodos, linha tênue entre a tradução erudita e a explicada: nem as palavras foram perfeitamente traduzidas (não buscamos correspondências exatas mas desconhecidas pela maioria do público), nem versos alongados para traduzir uma metáfora, manifesta muitas vezes em apenas uma palavra, um ritmo, uma expressão sonora, um gesto. Tarefa muito difícil! Seguimos o texto, as regras sintáticas, morfológicas e filológicas e a intuição de uma atriz.

Escolhemos como ofício dizer o indizível com todas as ferramentas que a cena teatral permitisse e, para tanto, estudamos não somente a estrutura da tragédia esquiliana, seus antecedentes, seu momento histórico, mas o entorno da palavra em ação. Procuramos entender o que o autor quis realizar, fazer em cena, fazer para os olhos e os ouvidos. Peremptório para nós foi tomar o texto encarnado. "Vimos" nele a coreografia, a música, o aceno. Um exemplo da modernidade pode ser elucidativo. $\mathrm{O}$ Manual mínimo do ator, de Dario Fo - ator, encenador e dramaturgo - registra uma experiência do autor ao assistir Macbeth, protagonizado por um outro grande ator e amigo. Dario, como ótimo profissional que é, observou diversas ações do seu colega que traduziam várias metáforas do texto, uma delas, a postura curvada ao contracenar com Lady Macbeth e que demonstrava o poder da rainha sobre ele no papel de Macbeth. Cumprimentando o amigo no camarim, Dario aponta vários momentos de sua 
atuação, vibrando com a interpretação que acabara de assistir. Porém, quando terminou, o ator perguntou estupefato:

- Eu faço isso? Quando? Eu não faço isso, não tive essa intenção. O diretor da peça, ouvindo a conversa, interpelou Dario:

- Eu te mato, Dario. (...) Você revelou-lhe o que ele estava fazendo. Amanhã ele não vai conseguir dizer mais nenhuma palavra com sentido lógico! $!^{17}$

Por tal motivo, na tradução aqui apresentada, deixamos-nos guiar por uma aluna que não dominava o grego, mas que, como atriz, saboreava sons e imagens. Uma atriz que, ouvindo traduções diferentes, explicações teóricas e linguísticas e, junto com elas o som do verso grego (principalmente em versos cuja sonoridade era a própria metáfora), interferisse no processo tradutório coletivo e encenasse para os tradutores cada frase. Deste modo, o efeito almejado, a cena, era corroborado (e checado) por outras ferramentas: a voz com suas notas variadas e modulações, o olhar, o movimento corporal e de deslocamento, a respiração e as pausas. E se, em algumas vezes, durante o processo, com a leitura do verso, as palavras não agradavam à equipe, tudo era repensado. Acrescentava-se um gesto, mudava-se o ritmo e as variações da voz na interpretação e, se preciso, mudava-se a tradução. A impressão causada era outra: mais clara, poética, viva, sem alongar ou intelectualizar a fala, mantendo sua "linguagem elevada" preconizada por Aristóteles.

Tentamos isentar a tragédia de suas muitas camadas aristocráticas a fim de recuperar aquelas estéticas, semânticas e culturais. Encenamos e alcançamos evitar um espetáculo enfadonho porque longo, ou porque ininteligível. Ainda era necessário submeter a provas a tradução, que foi apresentada a especialistas e leigos em espetáculo teatral e teve boa acolhida.

Fomos atentos também com o que devia permanecer obscuro: os nomes estranhos de reis e comandantes persas, Amístres, Artafanes, Megabates, Astapes, Artembares, Masistres, Imeu, Farandaques e outros mais. Inusitados, aparentemente grandiosos, mas, ironicamente definidos por Ésquilo como "reis vigias, submissos ao rei”, os nomes mantidos e treinados para a fala foram um teste imposto por Ésquilo. $\mathrm{O}$ conhecimento de que se trata de uma representação da Guerra de Salamina através das 
vozes dos vencidos, os persas, para o público vitorioso, os gregos, foi de grande valia. Carregamos o tom e permaneceu a ironia requintada cheia de imagens (até mesmo grotescas) criadas, porém, por metáforas brilhantes, afinal estamos falando de Ésquilo.

Podemos concluir que, para montar uma tragédia, com atores que desconhecem a língua grega, o método da tradução coletiva e sua experimentação como palavra pronunciada e realizada é eficaz. Acreditamos que, assim, a tragédia possa sair dos muros da academia e chegue até ao público comum, como na Ática do séc. V a.C.

\section{Referências}

AESCHYLUS. Aeschyli tragoediae. Persae. Edited by G. Murray. Oxford: Clarendon Press, 1955, p. 53-95.

Persae. In: http://el.wikisource.org/wiki/\%CE\%A0\%CE\%AD\%CF\% 81\%CF\%83\%CE\%B5\%CF\% 82 (acessado em 19/07/09, às 11:47h).

AESCHYLUS. Persae. In:

http://www.perseus.tufts.edu/cgibin/ptext?doc=Perseus\%3Atext\%3A1999.01.0011 (acessado em 23/07/09, às 10:55h).

ARAÚJO, A. R. G.; LEANDRO, M. C. X.; BARBOSA, T. V. R. As dificuldades de traduzir para teatro: o prólogo das Eumênides de Ésquilo. Cadernos de tradução. PGET-UFSC, Florianópolis, vol. II, n. 20, p. 101-124, 2007.

ARISTÓTELES. História dos animais, I. Tradução de Maria de Fátima Sousa e Silva. Lisboa: INCM, 2006.

BORGES, J.-L. A metáfora. In: Mihailescu, C.-A. (org.). Esse ofício do verso. Tradução de José Marcos Macedo. São Paulo: Companhia das Letras, 2000, p. 29-49.

de CAMPOS, H. Da tradução como criação e como crítica. In: (org.). Metalinguagem \& outras metas. Ensaios de teoria e crítica literária. São Paulo: Perspectiva, 1992, p. 31-48.

ÉSQUILO. Persas. Tradução de Manuel de Oliveira Pulquério. Coimbra: Instituto Nacional de Investigação Científica, 1992.

2004.

. Os persas. Tradução de Mário da Gama Kury. Rio de Janeiro: Zahar,

17 Fo, D. Manual mínimo do ator. Tradução de Luca Baldovino e Carlos David Szlak. São Paulo: SENAC, 1998, p. 103-104. 

197-228, 2002.

Os persas. Tradução de Jaa Torrano. Letras Clássicas. São Paulo, n. 6, p.

FO, D. Manual mínimo do ator. Tradução de Luca Baldovino e Carlos David Szlak. São Paulo: SENAC, 1998.

GOETSCH, S. Playing against the text. "Les Atrides" and the history of reading Aeschylus. TRD (1988-). New York, vol. XXXVIII, n. 3, autumn, p. 75-95, 1994 (in: http://www.jstor.org/stable/1146381 - acessado em 23/07/09, às 11:55h).

LARANJEIRA, M. Poética da tradução. Do sentido à significância. São Paulo: Edusp, 2003.

de OLIVEIRA, F. R. Duas ou três coisas sobre mitos e história: "Os Persas" de Ésquilo. Letras Clássicas. São Paulo, n. 6, p. 37-53, 2002.

POUND, Ezra. ABC of Reading. London: Faber \& Faber, 1991, p. 43.

SILVA, M. de F. A arte de construir o sucesso. Persas e Gregos em Salamina. Studia philologica Valentina. Valência, vol. IX, p. 111-130, 2006.

TORRANO, J. A. A. Mito e política na tragédia "Persas" de Ésquilo. Letras Clássicas. São Paulo, n. 6, p. 25-35, 2002.

VENUTI, L. Escândalos da tradução. Por uma ética da diferença. Tradução de Laureano Pelegrin. Bauru: EDUSC, 2002. 